\title{
Sustainable decision making under uncertainty: a case study in dredged material management
}

\author{
Alexander Scheffler ${ }^{1 *}$, Thomas Roth ${ }^{2}$ and Wolfgang Ahlf
}

\begin{abstract}
Background: The port of Lübeck is one of Germany's most important harbours for goods traffic to and from the Baltic Sea Region. Sedimentation from the River Trave requires regularly maintenance dredging as well as capital dredging operations in order to maintain the operational capability of the port. A range of solutions for sustainable dredged material handling exist and an assessment of these options often proves to be challenging for decision makers. Multi-criteria decision analysis (MCDA) provides decision support by processing different data sets and evaluating suitable options in a rational way. Using the stochastic multi-criteria acceptability analysis (SMAA)-TRI method with a modification of a previously developed computerised model for decision support in dredged material management, this study was performed to test decision support under uncertainty.

Results: The analysis endorsed that relocation to a dredged discharge pool and capping of an ammunition disposal site are viable options for Lübeck port. On the other hand, the use of dredged material from port expansion and its disposal on land are considered to be of very low sustainability under the given circumstances.

Conclusions: The case study demonstrates capabilities as well as boundaries of computer-aided decision making under the premise of incomplete information. Despite uncertainties, sustainable decision making is possible with appropriate MCDA methodologies although minimum requirements concerning both data quality and data quantity must be fulfilled. Consequently, one possible alternative could not be integrated into the case study due to incomplete information.
\end{abstract}

Keywords: Dredged material management; Sustainability; Decision support; MCDA; Uncertainty; Risk analysis

\section{Background}

For maintaining navigability and port expansion, dredging works are often essential for economic reasons. As new treatment technologies and beneficial uses of dredged material become more and more attractive from an economical point of view, decision makers are often confronted with a vast range of options and criteria to be assessed [1,2]. Each option is more or less marked by different advantages and risks, being economical, ecological and social in nature [3]. To give an example, one option might be considered to be the best from an ecological point of view, but brings in a row of economic risks. Adding even more complexity, local and regional aspects obviously are a source of uncertainty because

\footnotetext{
* Correspondence: scheffler@tu-harburg.de

'Hamburg University of Technology (TUHH), Institute of Environmental Technology and Energy Economics, Eissendorfer Str. 40, Hamburg 21073, Germany

Full list of author information is available at the end of the article
}

incomplete information is often available for options never applied on the specific location. Hokkanen et al. [4] state that 'environmental decisions are typically done under uncertain and incomplete information'. Such uncertainty strongly influences the decision maker's choice as Durbach and Stewart [5] have demonstrated. Regarding environmental decision making, a clear distinction between the terms uncertainty and risk is to be made [6]. Uncertainty is mostly characterised by absence of information, and credible outcomes cannot be assigned, while risk is a probability calculation of adverse consequences of a decision made.

Management decision making as a process can be described as an information gathering procedure to eliminate unfeasible options. The incipient dilemma of decision making is that, in early management stages, often a confusing number of theoretically available options are at hand, while only incomplete information is available. As the process proceeds, more and more information on the 
remaining options is available - leading to another drawback in decision making. At a certain point, the management process is obstructed by an overwhelming amount of information available, ranging from physicochemical measurements to stakeholder survey results [5]. For this case study, a scenario has been developed which takes place at an early management stage prompting uncertainty due to incomplete information. To solve such problems, Lahdelma and Salminen [7] recommend the use of the stochastic multi-criteria acceptability analysis (SMAA) approach repetitively during the decision process when additional and more precise information is gained. This approach also avoids the information overflow in later phases allowing less accurate information to be utilised for decision making.

\section{Situation at Lübeck}

The city of Lübeck is situated northern Germany and is connected via the river Trave to the Lübeck Bay. As in any other port, Lübeck has to carry out capital, maintenance, and environmental dredging resulting in often more or less contaminated dredged material which requires appropriate management solutions. Within the port of Lübeck, approximately 2.1 million $\mathrm{m}^{3}$ of sediment was dredged from 1986 to 2011, which equals a mean annual amount of $84,000 \mathrm{~m}^{3}$ dredged material. The actual amount of accrued dredged material lies between 1,000 and $608,000 \mathrm{~m}^{3}$ per year. Sixty two percent of this material is under the management responsibility of the city of Lübeck [8]. About one third of the dredged material, originating from the Trave River estuary, which obtains the status as a Federal Waterway, is managed by the federal waterways authorities. Only $5 \%$ of the dredged material is managed by private ports and marinas [8]. The river Trave is characterised by its low sedimentation rate of approximately $10,000 \mathrm{~m}^{3}$ per year. This value is much lower than that of the tide-influenced ports at Germany's coastal areas. Although a relatively small amount of sediments is dredged for maintenance purposes, a higher background burden of organic and inorganic substances in comparison to other ports occurs in some areas and has to be considered. The relative amount of dredged material to be relocated or beneficially used without need of treatment is rising due to reduction of contaminant sources and advanced wastewater treatment; approximately $40 \%$ compared to the overall volume [8]. However, pollution from abandoned industrial sites, like foundries, negatively influences sediment quality in some port areas and river sections of the Trave.

\section{MCDA scope}

In June/July 2012, a case study using MCDA methodology was performed in order to test its applicability for sitespecific conditions of port Lübeck. MCDA is an acronym standing for multi-criteria decision support and analysis and is basically a computerised method or tool for decision aiding and data processing. The main advantage of MCDA systems is their ability to process vast amounts of data from a wide range of topics. For instance, chemical sediment data and results of stakeholder questionnaires can be integrated into one computation allowing an interdisciplinary view of the problem to solve. These data are condensed to a single result, usually a ranking of the available management options according to the management goal. The general procedure of a MCDA analysis is as follows:

1. Definition of the overall management goal

2. Definition of available management options (called alternatives)

3. Definition of adequate indicators (called criteria) and data collection

4. Data entry and criteria weighting

5. Automatic calculation and display of results

6. Interpretation of results

Although avoiding the irrational human element in decision making, the results are not purely based on mathematics. Through weighting of the different indicators, expert knowledge or preferences of the decision-making process are included. Often the incorporation of knowledge of individuals or groups is claimed to create additional uncertainty $[3,6]$. Quite the contrary is the case for the responsibility of decision making, which remains exclusively with the decision makers [9]. This applies eminently regarding criteria weighting and result interpretation. Thus, it is not possible to ignore the decision maker's knowledge including his individual perspective and values [9].

There are many different MCDA approaches, both considering utilised algorithm and software. According to [10] and [11], following MCDA methods are frequently used in environmental management and planning:

- MAUT/MAVT (Multiattribute utility theory/ multiattribute value theory)

- AHP (Analytical hierarchy process)

Outranking methods, like PROMETHEE and ELECTRE III, as well as simple multi-attribute rating technique (SMART) and fuzzy logic-based MCDA systems are also used by US authorities, e.g. USACE (US Army Corps of Engineers), Department of Energy (DOE) and Environmental Protection Agency (EPA) [11]. MCDA methodology for dredged material management has been introduced and was successfully applied by the US Army Corps of Engineers and US Environmental Protection Agency $[1,12,13]$. A detailed description of two case 
studies of the usage on MCDA methodology in sediment management (New York/New Jersey harbour; Cocheco River) is given in [14]. Additional information on MCDA projects in US dredged material management is found in [15] and [16]. In Europe, MCDA techniques were applied by a Norwegian project for sediment management as discussed in [17] and [18]. In Spain, a case study has been carried out in order to prioritise areas in need of remediation and management options [19]. The SMOCS project in Europe also facilitated the use of MCDA methodology in sediment management [20]. Despite the approach applied at Lübeck, a commercial web-based MCDA expert system ('WebHIPRE', SMART/SWING algorithm) came in use in Gothenburg, Sweden [21]. While the Norwegian approach on MCDA use focussed much on stakeholder involvement, the aim of the case study presented here lies on incorporating sustainability under the constraint of limited data availability. To do so, several MCDA systems were assessed considering their suitability for use in the SMOCS project in 2011 [22]. However, both commercial and open source/freeware software solutions were included; the following paragraph deals exclusively with freely available software. Test models were applied to the different MCDA systems for assessment. For testing purposes, a management option considered being sustainable and a clearly unacceptable solution as well as four alternatives performing between these two were utilised in the software tests. In all MCDA solutions, both the worst and the best options were identified correctly; however, some differences occurred ranking the other alternatives. Other assessment criteria, like the capability of exporting data and results, are given in Table 1.

From the above evaluation, the method of choice was the SMAA-TRI approach for determining the most sustainable management solution. Developed by Hokkanen et al. [23], the SMAA approach allows bypassing problems considering incomplete information and uncertainty by inverse weight space analysis [5,6,24]. In addition, the SMAA algorithms are specially designed for problems involving multiple decision makers or stakeholders, using advantages of comprehensible expert knowledge and outweighing possible risks $[25,26]$. SMAA-TRI or SMAAIII is a variant of the SMAA method, allowing the established ELECTRE III algorithm to operate with imprecise criteria values and/or incomplete information [27]. Since its development in the late 1990s, the SMAA-TRI approach and its predecessors have been utilised successfully for management decisions, environmental planning as well as risk assessment [4,28-31]. Determining sustainable solutions is also of importance in dredged material management, for which the SMAA-TRI approach is eminently suitable.

\section{Results and discussion}

An advantage of the applied method and software is its transparency and easiness of application. The graphical user interface is clearly structured, and the results are relatively easy to interpret (see Figure 1). In contrast to the other mentioned studies, the applied software and method can easily applied by stakeholders without direct aid from scientific personnel. This fact is important for many decision makers are yet inexperienced dealing with MCDA methodology and therefore may reject its use if it is designed as a pure expert system. Despite the play of science, in this case a more consulting role, cooperation between science and port industry should not be seen as a one-way road. Science can introduce new management techniques and methods for enhancing sustainability performance of ports while practitioners provide expert knowledge, which would otherwise be inaccessible to scientists. Steady exchange of knowledge between science, industry and other stakeholders enhances environmental management deeply.

It should be pointed out that the SMAA approach is more suitable for eliminating unfavourable alternatives from the decision process rather than for determining one unique best solution [7]. Habitat creation at the dredged discharge pool 'Am Stau' could be identified as the most sustainable management option scoring of 0.94 out of 1 . Meaning that by $94 \%$ chance, this option is likely to match the set sustainability criteria. Both from economic and ecological points of view, this alternative represents a

Table 1 Assessed MCDA software in the SMOCS project

\begin{tabular}{|c|c|c|c|c|c|c|}
\hline Software & Method & Compatibility & Stability & Expert functions and data entry & Ease of use & Export/Import \\
\hline PRIME decisions & MAVT & $+/-$ & -- & ++ & + & + \\
\hline WinPre & AHP/SMART-SWING & - & $+/-$ & + & $+/-$ & + \\
\hline Open decision maker & AHP & ++ & ++ & $+/-$ & ++ & $+/-$ \\
\hline NSFES ॥ & Fuzzy logic & + & + & $+/-$ & $+/-$ & $+/-$ \\
\hline Facilitator & Outranking & ++ & ++ & $+/-$ & + & + \\
\hline jMAF & CDRSA (rough set) & + & ++ & ++ & + & ++ \\
\hline JSMAA & SMAA2/SMAA-TRI & ++ & ++ & ++ & ++ & + \\
\hline
\end{tabular}

++ , very good performance; + , good performance; $+/-$, acceptable performance; - , poor performance; -- , insufficient performance. All assessed software was available without charges at the time of the study. 


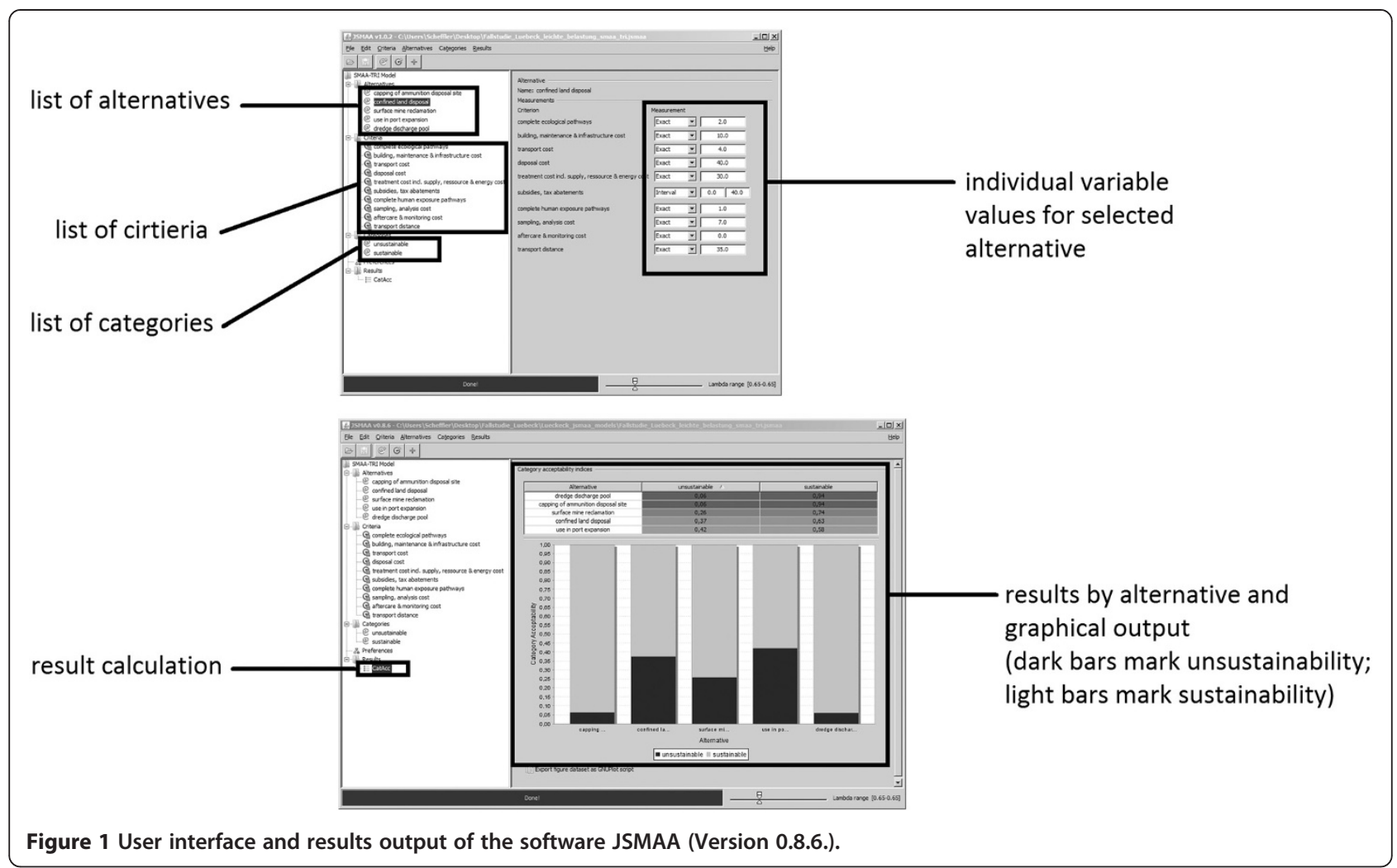

viable option for the Lübeck port as the transport costs are quite low $\left(4 € / \mathrm{m}^{3}\right)$. Besides that, there are no special treatment cost and disposal cost. Infrastructure and maintenance cost are also very low compared to other options (e.g. port expansion). Main advantages of this alternative are the low transport efforts alongside with its relevancy for wetland ecology. Being only $10 \mathrm{~km}$ afar from the place of dredging, GHG emissions and energy consumption of this alternative should be quite lower than other relocation options (e.g. capping of the former ammunition disposal site 'Walkyriengrund'). As stated before, a cessation of relocation to the dredge discharge pool would result in an environmental degradation - rendering this alternative even more attractive. However, effects of a cessation to local wetland ecology could not be quantified. That leads to another crucial point regarding data availability: According to [11] some MCDA methods, like MAUT/ MAVT, assume a perfect knowledge of the decision maker (within the MCDA assessment). This assumption does not apply for qualitative aspects in the reality of dredged material management, expert knowledge should not be neglected and decisions not purely be based on mathematical calculations. Additional statements of the DOE point to the usefulness of MCDA techniques as a good tool but not the only factor in decision making [11]. Although scoring the same for sustainability, capping of the former ammunition disposal site 'Walkyriengrund' seems less adequate from an ecological point of view due to its long transport distance of approximately $35 \mathrm{~km}$. From an economical point of view however, this alternative offers the grant of subsidies. Surface mine reclamation is to be considered as third best solution, obtaining an acceptability index of 0.74 . An advantage of this option is that former quarry in which the sediment is relocated only lies just $1 \mathrm{~km}$ afar from the dredging place. This option has quite high treatment costs of approximately $25 € / \mathrm{m}^{3}$ and its obvious impact on ecology is considered to be not viable under current conditions. The observation that one option is slightly more preferable than another although scoring equally, points to the fact that the decision makers experience is still a key factor in decision making. The two alternatives confined land disposal and use in port expansion scored relatively poor in MCDA assessment ( 0.63 and 0.58). The alternative confined land disposal had by far the highest disposal cost $\left(40 € / \mathrm{m}^{3}\right)$ and the second highest treatment cost $\left(30 € / \mathrm{m}^{3}\right)$ of all available options. In addition to that, the transport distance is $35 \mathrm{~km}$, same as capping of former ammunition disposal site. Confined land disposal was the only criteria that matched the strict target of only 1 human exposure pathways and can therefore be recommended for small amounts of highly contaminated dredged material. The use in port expansion, although just $8 \mathrm{~km}$ afar from the dredging place, is not considered to be economically viable due to its high treatment cost of $40 € / \mathrm{m}^{3}$ (including supply resource and energy cost). Therefore, these two options are considered applicable 
under special circumstances or in the absence of other alternatives. The complete MCDA assessment results are shown in Table 2.

MCDA methodology proved to be of great value for aiding decision making in dredged material management when several options are at hand. Although utilising model assumptions for the study, MCDA assessment results are in line with actual measures taken for sustainability improvement at the Lübeck port. The problem of uncertainty in early management stages could be handled by the SMAA-TRI approach, and solid results were obtained. However, data availability still is challenging. The non-integration of the management option of creating man-made islands as habitats for neither data was available, nor does practical experience exist currently in Lübeck regarding this option. This is in conformity with [7], stating that a certain degree of data quantity and accuracy are to be fulfilled for SMAA application. Dorini et al. [3] and Sparrevik et al. [32] suggest use of preliminary life cycle assessments (LCA) and economic analysis. A similar method of incorporating LCA results in MCDA has been applied by Prado-Lopez et al. [33]. A comparative stand-alone LCA assessment for dredged material management has been applied in the port of Gävle (Sweden) in 2011 [34]. However, these methods are not able to deal with incomplete or missing information. This problem could be bypassed by performing preceding (semi-)qualitative model simulations as described in [35] and [36]. In this case, the model simulation would provide data for the MCDA (e.g. estimated cost ranges) while simultaneously compensate one of the biggest weaknesses of MCDA methodology, that is considering sediment management as static rather than a dynamic process.

\section{Conclusions}

The Lübeck Port Authority reacted positively to the use of MCDA methodology and software as addition to established practices. During the study, it became obvious that there is a strong demand for non-expert easyto-use decision-supporting (software) solutions. These positive results are in contrast to case studies presented in [37] in which the results obtained from multi-criteria

Table 2 Ranking of management alternatives (two-category analysis; 1 = top rank, 5 = worst option)

\begin{tabular}{llc}
\hline Rank & Alternative name & $\begin{array}{c}\text { Acceptability } \\
\text { index }(\mathbf{0}, \mathbf{- 1})\end{array}$ \\
\hline 1 & Relocation to dredged discharge pool & $(0,94)$ \\
1 & Capping of former ammunition disposal site & $(0,94)$ \\
2 & Surface mine reclamation & $(0,74)$ \\
3 & Confined land disposal & $(0,63)$ \\
4 & Use in port expansion & $(0,58)$ \\
\hline
\end{tabular}

analysis were mostly ignored by the persons responsible. It is our perception that MCDA methodologies are likely to become a standard instrument in the framework of sediment management in future. However, it came clear that responsibility cannot simply be handed over to an MCDA solution. Both preferred alternatives have, although scoring equally, economic and ecological advantages - that is, subsidies for capping and low GHG emissions for dredged discharge pool. It is still the human element, the responsible decision maker, to do the final judgement on what action is to be taken. This is where MCDA methodology offers a more structured view on the different options, giving the decision maker a deeper insight into the aspects of the decision to be made. While the utilised SMAA-TRI method copes well with limitations in data availability, qualitative aspects of decision making still pose an obstacle. If neither data nor practical experience exists for a management option, this alternative cannot be incorporated in a MCDA assessment. The unintegrated alternative creating manmade islands as habitats provides an example for this. Besides decision support and stakeholder involvement capacities, the cooperation between the Hamburg University of Technology and the Lübeck Port Authority showed that MCDA can also function as a link between harbour industry and the scientific world. Transfer of up-to-date scientific knowledge to the sphere of economy can be realised by using MCDA methodologies, especially when dealing with issues of sustainability.

\section{Methods}

\section{Design of options and model criteria}

In recent years, sediment management came into focus of public attention and consequently a demand for sustainable solutions exists. In order to find the most sustainable available management option, various themed criteria are to be taken into consideration. To achieve this defined management goal, economically feasible, environmentally friendly and socially tolerable options are to be identified. Thus, available and potential options need to be further assessed. Except for the option capping of ammunition disposal site, which was performed as regular relocation for dredged material disposal, and the envisaged option habitat enhancement/man-made islands, all alternatives presented herein have been practiced in the past (see Figure 2 for details).

\section{Capping on ammunition disposal site}

In most cases, sediments of port Lübeck have very low contamination [8]. Hence, common practice is relocation of the dredged material to a Baltic Sea disposal site or on the nearby dredged discharge pool 'Am Stau' [8]. These methods are applied if no other beneficial use is 


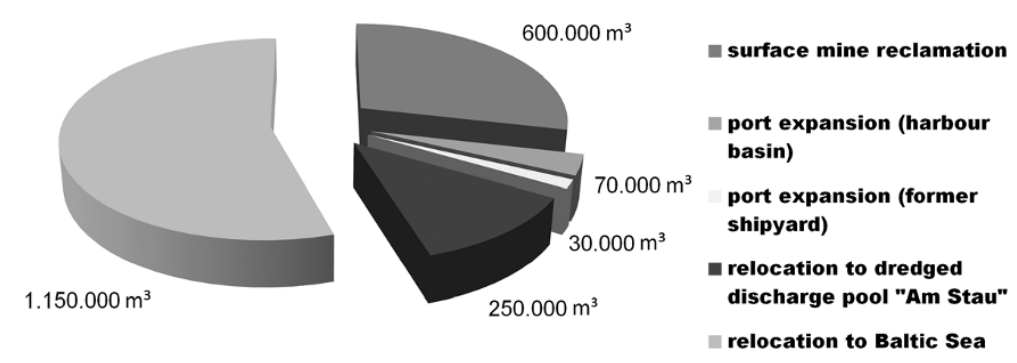

Figure 2 Destination of dredged material in port of Lübeck (1986 to 2011). Data source: Roth 2011.

economically or ecologically feasible. Relocation takes place according to the following legal frameworks:

- Joint Transitional Arrangements for the Handling of Dredged Material in German Federal Coastal Waterways (GÜBAK - WSV)

- EU legislation (including Water Framework Directive \& Waste Directive)

- HELCOM guidelines for dredged material disposal.

Relocation of uncontaminated or slightly contaminated dredged material is only allowed after extensive analysis of the physico-chemical properties of the sediment. In addition, an assessment of possible environmental and societal impacts is necessary. If required conditions are matched, the dredged material is relocated to a disposal site within the Lübeck Bay approximately $35 \mathrm{~km}$ east of the harbour. Location of the former ammunition disposal site 'Walkyriengrund' matches spatially almost exactly the dredged material disposal site, which offers a possible additional beneficial use of the dredged material as capping of the deposited ammunition for risk reduction.

\section{Habitat enhancement via relocation to a dredge discharge pool}

Uncontaminated or slightly contaminated dredged material from maintenance and capital dredging of the city of Lübeck and private marinas is usually relocated to the dredged discharge pool 'Am Stau'. The annual amount is approximately $10,000 \mathrm{~m}^{3}$ [8]. With an area of 24 ha, the dredged discharge pool is the last remaining disposal site of its kind within the city limits of Lübeck [8]. As well as for relocation at sea, assessments of physio-chemical sediment properties are mandatory. For the underlying soil of the dredged discharge pool, has higher geogenic and anthropogenic background values due to previous uses of the site, the indicating values for dredged material placement are to some extent higher than those for relocation at sea. Due to the relocation of dredged material, the area has evolved into a wetland-like site. It represents a valuable habitat for several birds (lapwing Vanellus vanellus; ruff Philomachus pugnax; common ringed plover Charadrius hiaticula; common snipe
Gallinago gallinago) and amphibian species, depending on on-going dredged material input. The area is also a stopover site for migrating birds and therefore has the status of a protected area under German Federal Law. Currently, a management concept for preserving this area is under development by the Lübeck Port Authority (LPA) in collaboration with local environmental authorities. Cessation of dredged material disposal would result in a deterioration of ecological quality as happened at the close-by dredged disposal pool 'Kattegatt' suffering from severe drying-up effects.

\section{Confined land disposal}

Dredged material with higher levels of contamination does not occur in higher volumes. It is usually relocated to appropriate confined land-based disposal sites. From 1986 to 2011 , only $5,000 \mathrm{~m}^{3}$ of considerably contaminated sediments accrued and were relocated to these confined disposal sites [8]. In case of the appearance of higher amounts of significantly contaminated dredged material, high disposal and transport cost prevent this option from being executed. The nearby waste disposal site Niemark is by German jurisdiction not allowed for storage of dredged material. Construction of a disposal site in Lübeck for dredged material proved to be not economically viable, and therefore, planning and permitting activities have been discontinued in 1996 [8].

\section{Harbour construction}

Accruing dredged material from capital dredging operations has been used twice in projects by the LPA for harbour construction and port expansion. In one case, $30,000 \mathrm{~m}^{3}$ of contaminated dredged material were used to fill a dock at the former shipyard Flenderwerft [8]. Another example represents the port expansion through filling a former harbour basin area at the Vorwerk Harbour with approximately $70,000 \mathrm{~m}^{3}$ of partially contaminated dredged material [8]. By separating the former dock from the main harbour basin via sheet pile walls and use of $\mathrm{VC}^{\circ}$ System - Ménard method for dredged material consolidation, a port expansion area of $22,800 \mathrm{~m}^{2}(190 \times 120 \mathrm{~m})$ has been constructed [8]. In the mid 1990s, execution of this novel method required 
a complicated procedure of permitting considering the following legislations:

- Water Management Act

- Water Act of the Federal State Schleswig-Holstein

- Environmental Protection Act of the Federal State Schleswig-Holstein

- Federal Waterways Act

- Dredged Material Concept of the Federal State Government of Schleswig-Holstein

Due to economic reasons, the relatively rare need of port expansion as well as the mentioned difficulties in the permitting process, beneficial use of dredged material in harbour construction is considered to be used as exceptional cases.

\section{Surface mine reclamation}

In 1988 , approximately $600,000 \mathrm{~m}^{3}$ of uncontaminated dredged material were used for reclamation of a nearby gravel quarry [8]. Although successful, this management option is considered today to be not viable both under ecological and economical aspects.

\section{Other management options}

Use in habitat enhancement is considered to be a future option for dredged material management in the form of creating man-made islands as breeding area for bird species. Currently, there is neither data nor practical experience for this management option in Lübeck existing. Other management solutions practiced in other German ports, like use in agriculture (Rostock), are considered to be inapplicable in Lübeck due to site- and sedimentspecific characteristics. Same can be said for sand separation technologies as the METHA facility (Hamburg). By use of hydro-cyclones, this technology separates the higher contaminated fine fraction from the relatively uncontained coarse fraction - resulting in volume reduction of sediments to be disposed [38]. Currently, a site-specific management and treatment strategy for contaminated dredged material is under development by the LPA. An overview of applied management options with their individual sediment volumes is to be found in Figure 2 .

The following management options were identified to be generally appropriate for dredged material handling in the port of Lübeck:

- Use as capping layer for a former ammunition disposal site

- Confined land disposal

- Habitat creation via relocation to dredge discharge pool 'Am Stau'

- Use in port construction

- Surface mine reclamation
Due to lack of verified case-specific data, the possible alternative creation of avifauna breeding habitat, which basically is the construction of man-made islands, was not taken into account for current case study. Advantages and disadvantages of the different management options were identified via stakeholder interviews as well as literature and database research.

\section{Sustainability criteria and model assumptions}

Sustainability has become a catchphrase in public and often seems to be an overused term. However, from a scientific point of view, an exact and widely accepted definition of sustainable management has not been found yet - this especially applies to the field of dredged material. According to [39], a sustainable (environmental) decision needs to fulfill the following requirements:

1. Environmentally sustainable

2. Socially acceptable/desirable

3. Politically expedient

4. Administratively achievable

5. Legislatively permissible

6. Technologically feasible

7. Economically viable

Based on these requirements, a definition for sustainability in dredged material management has been developed in the SMOCS project. Sustainable management of potentially contaminated sediment implies the application of procedures, techniques or approaches which widely

a) Avoid unconfined disposal or dumping at sea;

b) Minimise or mitigate adverse effects to environment, human health (including food safety and occupational safety) or other living resources (in particular marine life), infrastructure, amenities, geological resources (e.g. groundwater) or sites of archaeological or scientific interest (e.g. shipwrecks);

c) Allow, facilitate or support a beneficial, preferably economically viable, re-use of dredged material for engineered uses, agricultural or product uses or environmental enhancement;

d) Reduce the amount of accruing dredged material to be disposed;

e) Reduce content, concentration or bioavailability or harmful eco-toxic-relevant substances potentially contained within the dredged material or preferably destruct or otherwise completely remove such substances from the dredged sediment;

f) Do not interfere with other legitimate uses of the sea, such as fishery, aquaculture, navigation, tourism, coastal protection or nature conservation;

g) Do not negatively affect marine and upland infrastructure (e.g. cables and pipelines); 
Table 3 Criteria framework of the SMOCS project

\begin{tabular}{|c|c|c|}
\hline & & Criteria \\
\hline \multirow{8}{*}{ Environmental } & \multirow{3}{*}{ Contaminants } & Ecological hazard quotient \\
\hline & & Complete ecological exposure pathways \\
\hline & & Risk of contaminant/nutrient release \\
\hline & \multirow{3}{*}{ Biodiversity } & Expected loss of species \\
\hline & & Expected time to full re-colonisation (relocation options) \\
\hline & & Risk of infiltration by non-local biota \\
\hline & \multirow{2}{*}{ Other } & Release of climate gases \\
\hline & & Volume of remnants for disposal \\
\hline \multirow{11}{*}{ Economic } & \multirow{5}{*}{ Costs } & Transport cost \\
\hline & & Disposal cost \\
\hline & & Treatment cost \\
\hline & & Method/Infrastructure cost \\
\hline & & Public relation cost \\
\hline & \multirow{4}{*}{ Profit } & Subsidies \\
\hline & & Tax abatements \\
\hline & & Financial profit (e.g. selling beneficial use products) \\
\hline & & Reduced costs (to disposal) \\
\hline & \multirow{2}{*}{ Business environment } & Potential markets (beneficial use products) \\
\hline & & Economic demand (beneficial use products) \\
\hline \multirow{4}{*}{ Regulatory } & \multirow{2}{*}{ Availability and acceptance } & Available authorised sites \\
\hline & & Public acceptance (Concern Assessment results) \\
\hline & \multirow{2}{*}{ Legal compliance } & Required environmental impact assessments \\
\hline & & Required applications \\
\hline \multirow{18}{*}{ Social } & \multirow{2}{*}{ Impact on scenery/landscape } & Positively affected area \\
\hline & & Negatively affected area \\
\hline & \multirow{2}{*}{ Tourism } & Monetary loss (expected) \\
\hline & & Loss of tourists (expected) \\
\hline & \multirow{6}{*}{ Human health and amenities } & Created amenity area \\
\hline & & Odour nuisance \\
\hline & & Impairment of bathing waters \\
\hline & & Noise pollution \\
\hline & & Complete human exposure pathways \\
\hline & & Largest cancer risk for any path \\
\hline & \multirow{4}{*}{ Cultural heritage/science } & Number of affected archaeological sites \\
\hline & & Adverse effects on archaeological sites \\
\hline & & Distance to archaeological sites (closest) \\
\hline & & Distance to sites of scientific interest (closest) \\
\hline & \multirow{4}{*}{ Local economics } & Loss of jobs (expected) \\
\hline & & Loss of money (expected) \\
\hline & & Gain of jobs (expected) \\
\hline & & Monetary profit for local business \\
\hline
\end{tabular}




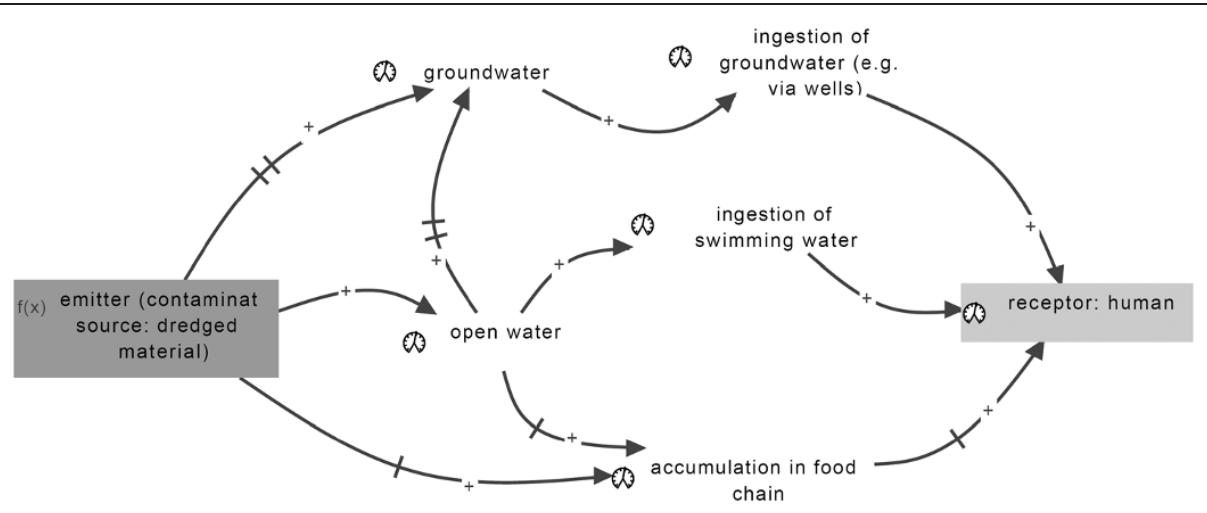

Figure 3 Emitter-receptor model for alternative capping of ammunition disposal site using software ConsideoProcessModeler.

h) Do not negatively affect existing or predictable future land uses, such as agriculture and forestry, transportation and traffic or housing development and

i) Utilise the Best Environmental Practice (BEP) approach according to Annex II of the 1992 Helsinki Convention to reach the article mentioned above.

A composed set of sustainability criteria has been modified for use in case-specific MCDA analysis of dredged material handling for the port of Lübeck. In the framework of the Project 'SMOCS', a MCDA framework has been developed, containing a list of criteria suitable for MCDA analysis [40,41]. This compilation provides aid for decision makers in choosing adequate casespecific data. However, due to case-specific data availability, use of the overall 41 criteria within the framework is constrained. In fact, only for a minority of the criteria set data are usually available for different alternatives. For instance, neither of the alternatives in the Lübeck case study had a measurable impact on bathing waters nor had been a risk of infiltration of non-local biota. Table 3 shows the complete list of criteria from the SMOCS framework. The available criteria are in italics.

Sustainability characteristics (ecology, economy, social aspects) were integrated into a model for the MCDA software JSMAA 0.8.6 using criteria and their values as sustainability indicators. For there is currently no large scale dredging operation in the port of Lübeck planned, several model assumptions were made for the MCDA analysis. Although, utilising actual data, this case study assesses potential handling options of a hypothetical large-scale dredging operation.

\section{Social criteria}

We consider human health issues as one of the prime aspects in sediment management. Even if the dredged material is only slightly contaminated, bioavailability, concentration in the food chain as well as long-term and combined effects of contaminants may still be an issue [42]. As the dredged material only obtains minimal contamination, an absence of data suitable for MCDA analysis occurred. Therefore, the individual pathways of potential contaminations were modelled for each alternative, using the software 'ConsideoProcessModeler' (version 7.5), a software package designed for simulating dynamic systems. A simple qualitative model estimating pathways of contaminant release and transport has been developed for each alternative. Figure 3 shows the emitter-receptor model for the alternative capping of ammunition disposal site. As shown, the receptor (human) does not come in direct contact with the emitter (dredged material), but several pathways indirectly reach the receptor. Special attention was given to the transport media. The impact strength is set to an equal rate for every variable interconnection while different time delays are at hand, but were not relevant for MCDA analysis.

The impact on local economy and tourism could not be assessed as the actual applied management options at Lübeck port were to variable both in dredged material volume and project scale.

\section{Table 4 Lübeck case study model assumptions}

\begin{tabular}{ll}
\hline Variable & Modell assumptions \\
\hline Dredged material volume & $10,000 \mathrm{~m}^{3}$ \\
Level of contamination & Low (Class ecotoxicology 1) \\
Type of dredging & Capital dredging for port expansion \\
Number of dredging campaigns & 1 \\
Number of available alternatives & 5 (6, including habitat creation) \\
Unit of volume & $\mathrm{m}^{3}$ \\
Unit of distance & $\mathrm{km}$ \\
Monetary unit & EUR \\
Management stage & Planning phase (early) \\
\hline
\end{tabular}




\section{Ecological criteria}

Derivation of ecological data for use in MCDA systems requires either a specific investigation or a first attempt using partly a life cycle approach. The sum of all possible ecological pathways for each alternative was derived as one indicator for possible ecological risks. As analogue to the emitter-receptor model for social criteria, ecological pathways were modelled using the software ConsideoProcessModeler ${ }^{\bullet}$ A global impact of the dredged material management process is emission of greenhouse gases (GHG). This aspect was taken into account by integrating the variable transport distance as indicator for energy consumption and GHG emissions. The unit of measurement was kilometres $(\mathrm{km})$.

\section{Economic criteria}

A set of indicators for economic feasibility was derived previous MCDA studies and stakeholder interviews. The following criteria were integrated into the MCDA model covering all dredged material management stages:

- Transport cost

- Treatment cost

- Building and maintenance cost including supply, raw material and energy costs

- Disposal cost

- Sampling and analysis costs

- Aftercare and monitoring cost

- Subsidies and tax abatements

Inclusion of raw material and energy cost is an additional indicator for resource and energy consumption. Subsidies and tax abatements are only granted for new construction projects.

\section{Model assumptions}

For this case study, an amount of $10,000 \mathrm{~m}^{3}$ slightly contaminated dredged material was assumed. As sediment quality, Class ecotoxicology $_{1}$ according to [42] was assumed, meaning that there are no or low eco-toxicological effects. Another model assumption was the materials' physicochemical suitability for the alternatives capping of ammunition disposal site and habitat enhancement via relocation to dredge discharge pool. According to German legislation, regular performed maintenance dredging operations are excluded from tax abatements or subsidies. For proper integration of the criterion subsidies and tax abatements, a single capital dredging campaign for port expansion was assumed. MCDA strategies slightly differ depending on the management phase they are utilised in. As mentioned earlier, phases of the management process suffer most from uncertainty due to lack of data quantity. Therefore, this management phase has been chosen for testing robustness of the model. The complete model assumptions are shown in Table 4.

The used SMAA-TRI approach within the software JSMAA (version 0.8.6) allows defining categories of alternative ranking. Such categories are used to distinguish between favourable and unfavourable variable attributes by defining criteria limit values. For the case study of Lübeck port, the two following categories were initially defined:

- Sustainable (favoured)

- Unsustainable (least favoured)

These categories were in compliance with both legislative frameworks and expert knowledge provided by the LPA and the BfG (German Waterways Authority). Information regarding categorisation was gathered via stakeholder interviews and data acquisition. For instance, treatment cost above $25 € / \mathrm{m}^{3}$ sediment were seen as not feasible from an economical perspective. Another example is that subsidies, ranging from 5\% up to $40 \%$ are only granted for non-maintenance dredging operations or infrastructural advancement. Options ineligible for assistance ( $0 \%$ subsidies) were categorised as not favoured. This accounted only to the option habitat enhancement via relocation to dredge discharge pool for it is mainly used for regularly performed maintenance dredging operations. The level of societal and ecological sustainability/ favourability was set to a rather strict level: all options above one single pathway were categorised as unfavourable.

\section{Abbreviations \\ AHP: analytic hierarchy process; BfG: Bundesamt für Gewässerkunde (Federal Waterways Authority); DOE: Department of Energy; EPA: Environmental Protection Agency; EUR: Euro(currency); GHG: greenhouse gas; $\mathrm{m}^{3}$ : cubic metre; km: kilometre; LCA: life cycle assessment; LPA: Lübeck Port Authority; MAUT/MAVT: multiattribute utility theroy/multiattribute value theory; MCDA: multi-criteria decision support and analysis; METHA: mechanical treatment and dewatering of harbour sediments; SMART: simple multi-attribute rating technique; SMOCS: sustainable management of contaminated sediments; USACE: US Army Corps of Engineers; TUHH: Technische Universität Hamburg- Harburg (Hamburg University of Technology).}

\section{Competing interests}

There are no competing interests, neither financial nor otherwise.

\section{Authors' contributions}

AS conceived of the study and carried out the MCDA analysis. TR participated in the study design and provided additional site-specific information and data. WA participated in study coordination and result interpretation. The manuscript was drafted and approved by all authors.

\section{Acknowledgements}

This case study has been carried out in the context of the EU-SMOCS project (Sustainable Management of Contaminated Sediment in the Baltic Sea) in cooperation with the Lübeck Port Authority (LPA), which is acknowledged gratefully. This publication was supported by the German Research Foundation (DFG) and the Hamburg University of Technology (TUHH) in the funding programme 'Open Access Publishing'. 


\section{Author details}

${ }^{1}$ Hamburg University of Technology (TUHH), Institute of Environmental Technology and Energy Economics, Eissendorfer Str. 40, Hamburg 21073, Germany. ${ }^{2}$ Lübeck Port Authority (LPA), Ziegelstrasse 2, Lübeck 23539, Germany.

Received: 8 December 2013 Accepted: 23 February 2014 Published: 5 March 2014

\section{References}

1. Linkov I, Satterstrom FK, Kiker G, Seager TP, Bridges T, Gardner KH, Rogers $\mathrm{SH}$, Belluck DA, Meyer A: Multicriteria decision analysis: a comprehensive decision approach for management of contaminated sediments. Risk Anal 2006, 26(1):61-78

2. SMOCS (Sustainable Management of Contaminated Sediment in the Baltic Sea): Sustainable management of contaminated sediments - guideline. In Linköping, Sweden: Swedish Geotechnical Institute; 2013.

3. Dorini G, Kapelan Z, Azapagic A: Managing uncertainty in multiple-criteria decision making related to sustainability assessment. Clean Techn Environ Policy 2011, 13:133-139.

4. Hokkanen J, Lahdelma R, Salminen PA: Multicriteria decision support in a technology competition for cleaning polluted soil in Helsinki. In J Environ Manage 2000, 60:339-348.

5. Durbach IN, Stewart TJ: An experimental study of the effect of uncertainty representation on decision making. Eur J Oper Res 2011, 214:380-292.

6. Stewart TJ: Dealing with uncertainties in MCDA. In Multiple Criteria Decision Analysis: State of the Art Surveys. 78th edition. Edited by Figueira J, Greco S, Ehrgott M. Springer New York/USA: International Series in Operations Research \& Management Science; 2005:445-466.

7. Lahdelma R, Salminen P: Stochastic multicriteria acceptability analysis (SMAA). In Trends in Multiple Criteria Decision Analysis, International Series in Operations Research and Management Science. Edited by Ehrgott. New York/ USA: Springer; 2010:285-315.

8. Roth T: Bericht zum Verbleib des Baggergutes. In Official Report Of The Municipal Administration Of Lübeck. Lübeck: Stadtverwaltung Lübeck; 2011.

9. Tsoukiàs A: A qualitative approach to face uncertainty in decision models. Decis Support Syst 1994, 12:287-296.

10. Linkov I, Sahay S, Kiker G, Bridges T, Seager TP: Multi-criteria analysis: a framework for managing contaminated sediments. In Strategic Management of Marine Ecosystems. Proceedings of the NATO Advanced Study Institute on Strategic Management of Marine Ecosystems Nice, France 1-11 October 2003. NATO Science Series N: Earth and Environmental Series Volume 50 2005. Edited by Levner E. Amsterdam: IOS Press/Springer; 2005:271-297.

11. Linkov I, Varghese SJ, Seager TP, Kiker G, Bridges T: Multi-criteria decision analysis: a framework for structuring remedial decisions at contaminated sites. In Comparative Risk Assessment and Environmental Decision Making. Edited by Linkov I, Ramadan AB. Amsterdam: Kluwer Academic Publishers; 2004:15-54

12. Stansbury J, Bogardi IK, William E: Risk-cost analysis under uncertainty of the disposal of contaminated dredged material. In Water Resources Engineering Risk Assessment. NATO ASI Series Volume 29. Edited by Ganoulis J. Berlin/Heidelberg, Germany: Springer; 1991:283-310.

13. Yatsalo BI, Kiker GA, Kim SJ, Bridges TS, Seager TP, Gardner K, Satterstrom FK Linkov I: Application of multicriteria decision analysis tools to two contaminated sediment case studies. Integr Environ Assess Manag 2007 3(2):223-233.

14. Linkov I, Moberg E: Multi-criteria decision analysis. environmental applications and case studies. Edited by Glenn W, Suter III. New York: Press Taylor \& Francis Group; 2012:21-67.

15. Kiker GA, Linkov I, Bridges T: Integrating comparative risk assessment and multi-criteria decision analysis: working through wicked problems and their impossible solutions. In NATO Science for Peace and Security Series Environmental Security in Harbours and Coastal Areas. Edited by Linkov I, Kiger G. Heidelberg/Berlin, Germany: Springer; 2007:37-51.

16. Menzie CA, Booth P, Law SA, von Stackelberg K: Use of decision support systems to address contaminated coastal sediments: experience in the United States. In Decision Support Systems for Risk-Based Management of Contaminated Sites. Edited by Marcomini A, Suter GW. Critto A. New York, USA: Springer; 2009:281-310.

17. Oen AMP, Sparrevik M, Barton DN, Nagothu US, Ellen GJ, Breedveld GD, Skei J Slob A: Sediment and society: an approach for assessing management of contaminated sediments and stakeholder involvement in Norway. J Soil Sediment 2010, 10:202-208

18. Sparrevik M, Breedveld GD: From ecological risk assessments to risk governance: evaluation of the Norwegian management system for contaminated sediments. Integr Environ Assess Manag 2010, 6(2):240-248.

19. Alvarez-Guerra M, Canis L, Voulvoulis N, Viguri JR, Linkov I: Prioritization of sediment management alternatives using stochastic multicriteria acceptability analysis. Sci Total Environ 2010, 408:4354-4367.

20. Rostmark S, Suzdalev S: Multicriteria analysis for dredging and treatment: case study - concept selection. Linköping, Sweden: Swedish Geotechnical Institute; 2013:16.

21. Falemo S, Bergmann R: Multi-Criteria Decision Analysis Application in the Port of Gothenburg. In Linköping, Sweden: Swedish Geotechnical Institute; 2013.

22. Scheffler A, Ahlf W: Nachhaltiges Management von belastetem Baggergut -Leitfaden und Entscheidungshilfen des SMOCS-Projektes. In Tagungsband des 7. Rostocker Baggergutseminars 25. - 26. September 2012. Edited by Henneberg M, Neumann R. Putbus: Wissenschaftsverlag; 2012:1-26.

23. Hokkanen J, Lahdelma R, Mietinnen K, Salminen PA: Determining the implementation order of general plan by using a multikriteria method. J Multi-Criteria Decis Anal 1998, 7:273-284.

24. Tervonen T: JSMAA - open source software for SMAA computations. Int J Syst Sci 2014, 45(1):69-81. Published online Feb 2013: doi:10.1080/ 00207721.2012 .659706

25. Lahdelma R, Hokkanen J, Salminen P: SMAA - Stochastic multiobjective acceptability analysis. Eur J Oper Res 1998, 106:137-143.

26. Lahdelma R: Pseudo-criteria versus linear utility function in stochastic multi-criteria acceptability analysis. Eur J Oper Res 2002, 141:454-469.

27. Tervonen T, Figueira JR, Lahdelma R, Salminen P: SMAA-III - a simulationbased approach for sensitivity analysis of ELECTRE III. In Real-Time and Eliberate Decision Making. Edited by Linkov. New York, USA: Springer; 2008:241-253.

28. Lahdelma R, Salminen P, Hokkanen J: Using multicriteria methods in environmental planning and management. Environ Manage 2000, 26(6):595-605

29. Kangas AS, Kangas J, Lahdelma R, Salminen P: Using SMAA-2 method with dependent uncertainties for strategic forest planning. Forest Policy Econ 2006, 9(2):113-125.

30. Menou A, Benallou A, Lahdelma R, Salminen P: Decision support for centralizing cargo at a Moroccan airport hub using stochastic multicriteria acceptability analysis. Eur J Oper Res 2010, 204(3):621-629.

31. Tervonen T, Linkov I, Steevens J, Chappell M, Figueira JR, Merad M: Risk-based classification system of nanomaterials. J Nanopart Res 2009, 11(4):757-766.

32. Sparrevik M, Saloranta T, Cornelissen G, Eek E, Fet AM, Breedveld GD, Linkov I: Use of life cycle assessments to evaluate the environmental footprint of contaminated sediment remediation. Environ Sci Technol 2011, 45:4235-4241.

33. Prado-Lopez V, Seager TP, Chester M, Laurin L, Bernado M, Tylock S: Stochastic multi-attribute analysis (SMAA) as an interpretation method for life-cycle assessment (LCA). Int J Life Cycle Assess 2013. doi:10.1007/ s11367-013-0641-x.

34. Bergman Y, Lundberg Y, Sköld YA: Standalone Life Cycle Assessment on Two Treatment Methods for Contaminated Sediments. Linköping, Sweden: Swedish Geotechnical Institute; 2012:53.

35. Brajnik G, Lines M: Qualitative modeling and simulation of socioeconomic phenomena. J Artif Soc Soc Simulat 1998, 1(1):1-22.

36. Slob AF, Gerrits L: The dynamics of sedimentary systems and the whimsicality of policy processes. J Soils Sediment 2007, 7(5):277-284.

37. Andersson A, Grönlund Å, Åström J: "You can't make this a science!"analyzing decision support systems in political contexts. Gov Inform Q 2012, 29:543-552.

38. Detzner H-D, Schramm W, Döring U, Bode W: New technology of mechanical treatment of dredged material from Hamburg. Water Sc Technol 1998, 37(6-7):337-343.

39. Apitz SE, Elliot M, Fountain M, Galloway TS: European environmental management: moving to an ecosystem approach. Integr Environ Assess Manag Jan 2006, 2(1):80-85.

40. Lundberg K, Ohlsson Y, Andersson-Sköld Y, Bergman R, Falemo S, Edeskär T, Scheffler A: Dredging contaminated sediments in the Baltic sea - a guide 
to sustainability assessment tools. Linköping, Sweden: Swedish Geotechnical Institute; 2013:60.

41. Lundberg K, Kempiene J, Bergman R, Wirska B, Scheffler A: Sustainability criteria for decision support when managing dredged contaminated sediment in the Baltic sea region. Linköping, Sweden: Swedish Geotechnical Institute: 2013:35.

42. Ahlf $\mathrm{W}$, Hollert $\mathrm{H}$, Neumann-Hensel $\mathrm{H}$, Ricking M: A guidance for the assessment and evaluation of sediment quality: a German approach based on ecotoxicological measurements. J Soil Sediment 2002, 2(1):37-42.

doi:10.1186/2190-4715-26-7

Cite this article as: Scheffler et al:: Sustainable decision making under uncertainty: a case study in dredged material management. Environmental Sciences Europe 2014 26:7.

\section{Submit your manuscript to a SpringerOpen ${ }^{\circ}$ journal and benefit from:}

- Convenient online submission

- Rigorous peer review

- Immediate publication on acceptance

- Open access: articles freely available online

- High visibility within the field

- Retaining the copyright to your article 